\title{
THE ROLE OF GYPSUM IN PORTLANDITE STONE STRUCTURE FORMATION
}

\author{
Yaroslaw Yakymechko ${ }^{1, *}$, Bogdan Chekansky ${ }^{1}$
}

DOI: dx.doi.org/10.23939/chcht11.01.093

\begin{abstract}
The hydration of calcium oxide has been examined in the presence of $\mathrm{SO}_{4}{ }^{2-}$. The conditions, under which portlandite stone with the best physico-mechanical properties was formed, have been determined. The hardening conditions affect the phase composition and microstructure of portlandite stone with a bihydrated gypsum. The mechanism of $\mathrm{CaO}$ hardening has been determined in the presence of $\mathrm{SO}_{4}{ }^{2-}$ ions.
\end{abstract}

Keywords: quicklime, portlandite, hydration hardening, activated gypsum.

\section{Introduction}

During non-autoclaved insulating aerated concrete production the structure of cement stone is formed at high water/cement ratio $(0.5-0.9)$. Such crystal phases as etringite and portlandite have a significant influence on the concrete strength, especially at the early stages of hardening.

Portlandite is an important component of cement stone. The role of portlandite during $\mathrm{C}_{3} \mathrm{~S}$ hardening is described in $[1,2]$. The authors assumed that $\mathrm{Ca}(\mathrm{OH})_{2}$ layers are incorporated between the packs of tobermorite phases and thus the solid solution is formed. M. Sanytskyi and L. Shpynova [3, 4] present calcium hydroxide as a matrix to form calcium hydrosilicates of various basicity. The structure of hydrated compounds is formed due to isomorphic substitution and introduction of $(\mathrm{OH})_{4}{ }^{4-}$ groups onto $\left[\mathrm{SiO}_{4}\right]^{4-}$ tetrahedron.

Portlandite is a positive factor to form crystal framework of cement stone. During the first period of $\mathrm{C}_{3} \mathrm{~S}$ interaction the $\mathrm{C}_{3} \mathrm{SH}_{\mathrm{x}}$ primary hydrate is formed, which is $\mathrm{Ca}(\mathrm{OH})_{2}$ according to [5]. $\left[\mathrm{SiO}_{4}\right]^{4-}$ groups are placed in its

\footnotetext{
${ }^{1}$ Lviv Polytechnic National University

12 S. Bandera St., 79013 Lviv, Ukraine

*sylikat@lp.edu.ua

(C) Yakymechko Ya., Chekansky B., 2017
}

tetrahedral pores. The portlandite crystals growth on the cement surface, as well as in the pores provides the formation of cement stone primary structure. Then $\left[\mathrm{SiO}_{4}\right]^{4-}$ tetrahedra condensation in the solid phase, $\mathrm{Ca}(\mathrm{OH})_{2}$ leaching and its crystallization in the pores as portlandite occur.

The important elements of alite stone crystal structure are hexagonal lamellar crystals of portlandite influencing construction and technical properties of cement. Portlandite content in cement stone at the age of 360 days is $18-20 \%$ (to calculate for $\mathrm{CaO}$ ). At leaching (for example, during filtration of water through concrete) the $\mathrm{Ca}(\mathrm{OH})_{2}$ content decreases and stone strength becomes low. Thus, the decrease in $\mathrm{Ca}(\mathrm{OH})_{2}$ amount by 15-30\% (relative to the total content) decreases the strength by $40-50 \%$ [6].

Gypsum is also an important component of Portlandcement. It is well-known that gypsum affects setting [7]. Since cement without gypsum has a short setting time and bad physico-mechanical properties, it cannot be used for construction works. The lack of gypsum results in small amount of formed etringite and hence, low mechanical strength. At the same time, the excess of gypsum leads to the expansion and destroys the structure because the secondary etringite is formed [8].

In the presence of gypsum in a liquid state the colloidal particles of $\mathrm{Ca}(\mathrm{OH})_{2}$ transform into crystal portlandite in the form of hexagonal laminae. The gypsum concentration of $0.2 \mathrm{~mol}$ per $100 \mathrm{~mol}$ of water at $298 \mathrm{~K}$ is the most optimum condition of the process [9]. The greatest amount of portlandite is formed in the cement stone with gypsum optimal content and the best physicomechanical characteristics. The optimum content of gypsum is when it is possible to obtain $\mathrm{C}_{3} \mathrm{~A} \cdot \mathrm{CaSo}_{4} \cdot 12 \mathrm{H}_{2} \mathrm{O}$.

There is a directly proportional dependence between gypsum content, portlandite amount and stone physico-chemical properties. At gypsum optimum content the greatest amount of portlandite is observed and the 
cement stone is of maximum strength [10]. The increase in gypsum content decreases a number of micropores of $50-200 \mu \mathrm{m}$ size. The reason is the formation of the enhanced amount of etringite and portlandite crystallization as large hexagonal laminae.

So, the aim of the present work is to establish the role of gypsum while forming portlandite stone structure at high water content and high concentration of $\mathrm{Ca}^{2+}$ ions in the liquid phase, that is usual for the production of nonautoclaved aerated concrete.

\section{Experimental}

To obtain the compositions we used quicklime and gypsum plaster. The quicklime properties are given in Table 1. Activated gypsum in a suspension form was obtained via rapid mixing of gypsum plaster at water/ gypsum ratio of 2.0 for $30 \mathrm{~min}$. As a result of hydration the colloid system of bihydrated gypsum was formed.

The chemical composition of lime, Portlandcement and binding compositions were determined using the chemical analysis and X-ray spectroscopy (ARL $9800 \mathrm{XP}$ spectrometer).

The phase state of hydration products was determined using XRD analysis. The samples were analyzed by DRON-3.0 diffractometer using $\mathrm{CuK}_{\alpha}$ radiation of BSV-1 tube. DTA analysis was used for investigations of the starting and resulting compounds in the systems: $\mathrm{CaO}-$ chemical additive and $\mathrm{CaO}-$ Portlandcement-activated gypsum. Derivatogramms were recorded using Paulik-Paulik-Erdey derivatograph Q-1500 D.

The morphology and habitus of resulting products were studied using the electron microscopy (JEM-100CX II microscope). Petrographic analysis (MIN-8 microscope) was used to determine the crystal form, pleochroism, cleavage and refractive index.

The physico-mechanical properties of the composites were determined using cubic samples of $2 \times 2 \times 2 \mathrm{~cm}$. The effect of additives on the lime paste yield was determined in liters per $1 \mathrm{~kg}$ of quicklime during wet liming of $200 \mathrm{~g}$ of grinded quicklime.

The size of hydrated lime particles was determined by measuring the rate of lime sedimentation and lime continuous weighing.

\section{Results and Discussion}

The important factor affecting the physicomechanical properties of the cement stone is the presence of electrolyte, namely $\mathrm{SO}_{4}{ }^{2-}$ ions, in the pores. We studied the interference of gypsum plaster and quicklime on their hydration. Fig. 1 shows the effect of lime content on the setting time of gypsum plaster. The increase in quicklime content till $30.0 \mathrm{wt} \%$ considerably influences the structure formation. Further increase in $\mathrm{CaO}$ content sharply reduces a setting time. While using hydrated lime the beginning of gypsum setting is delayed.

The introduction of quicklime to the composition (Table 2) increases the stone strength. Moreover, the maximum strength is observed at $\mathrm{CaO}$ content of $30.0 \mathrm{wt} \%$ that coincides with a maximum value of setting beginning. While using hydrated lime we observe the linear dependence of strength decrease with the increase in lime content in the composition. Thus, the increase in early strength of the composition based on quicklime is provided by $\mathrm{CaO}$ hydration hardening. The joint use of quicklime and gypsum provides the increase in strength and coefficient of stone softening till $0.73-0.80$.

Table 1

Construction and technical properties of quicklime

\begin{tabular}{|c|c|c|}
\hline \multirow{2}{*}{ Index } & \multicolumn{2}{|c|}{ Lime } \\
\hline & Low-active lime & Medium-active lime \\
\hline $\mathrm{CaO}$ total content, wt \% & 91.1 & 95.6 \\
\hline $\mathrm{MgO}$ content, wt \% & 1.7 & 0.9 \\
\hline Insoluble additives, wt \% & 5.1 & 0.9 \\
\hline $\mathrm{CO}_{2}$ content, wt $\%$ & 0.9 & 1.7 \\
\hline $\mathrm{H}_{2} \mathrm{O}$ content, wt $\%$ & 1.2 & 0.9 \\
\hline Total, wt \% & 100.0 & 100.0 \\
\hline Free $\mathrm{CaO}_{\text {theor }}$, wt $\%$ & 86.4 & 90.8 \\
\hline $\mathrm{CaCO}_{3}$ content, wt $\%$ & 2.0 & 3.8 \\
\hline $\mathrm{Ca}(\mathrm{OH})_{2}$ content, wt $\%$ & 4.8 & 3.6 \\
\hline $\begin{array}{l}\text { Time for achieving hydration degree } \\
\text { of } 80 \%(\mathrm{EN} 459) \text {, min }\end{array}$ & 5.0 & 3.0 \\
\hline
\end{tabular}


Table 2

Physico-mechanical properties of lime-gypsum stone

\begin{tabular}{|c|c|c|c|c|c|c|c|}
\hline \multicolumn{3}{|c|}{ Binder composition, wt $\%$} & \multirow[b]{2}{*}{ Water/Solid } & \multicolumn{3}{|c|}{ Compression strength, MPa after days } & \multirow{2}{*}{$\begin{array}{l}\text { Softening } \\
\text { coefficient }\end{array}$} \\
\hline Quicklime & $\begin{array}{c}\text { Hydrated } \\
\text { lime }\end{array}$ & $\begin{array}{c}\text { Gypsum } \\
\text { G-5 }\end{array}$ & & 1 & 7 & 28 & \\
\hline- & - & 100 & 0.65 & 5.10 & 5.82 & 6.21 & 0.45 \\
\hline 5 & - & 95 & 0.62 & 5.56 & 6.75 & 7.01 & 0.56 \\
\hline 10 & - & 90 & 0.53 & 6.84 & 7.98 & 8.02 & 0.65 \\
\hline 20 & - & 80 & 0.50 & 7.35 & 8.87 & 9.22 & 0.73 \\
\hline 30 & - & 70 & 0.51 & 8.56 & 9.21 & 10.28 & 0.80 \\
\hline 40 & - & 60 & 0.62 & 8.98 & 7.45 & 6.43 & 0.65 \\
\hline- & 5 & 95 & 0.60 & 4.56 & 5.01 & 5.23 & 0.56 \\
\hline- & 10 & 90 & 0.59 & 4.21 & 4.55 & 4.60 & 0.60 \\
\hline- & 20 & 80 & 0.66 & 4.02 & 4.20 & 4.55 & 0.62 \\
\hline- & 30 & 70 & 0.70 & 3.78 & 3.80 & 3.85 & 0.55 \\
\hline- & 40 & 60 & 0.73 & 3.20 & 3.54 & 3.56 & 0.51 \\
\hline
\end{tabular}

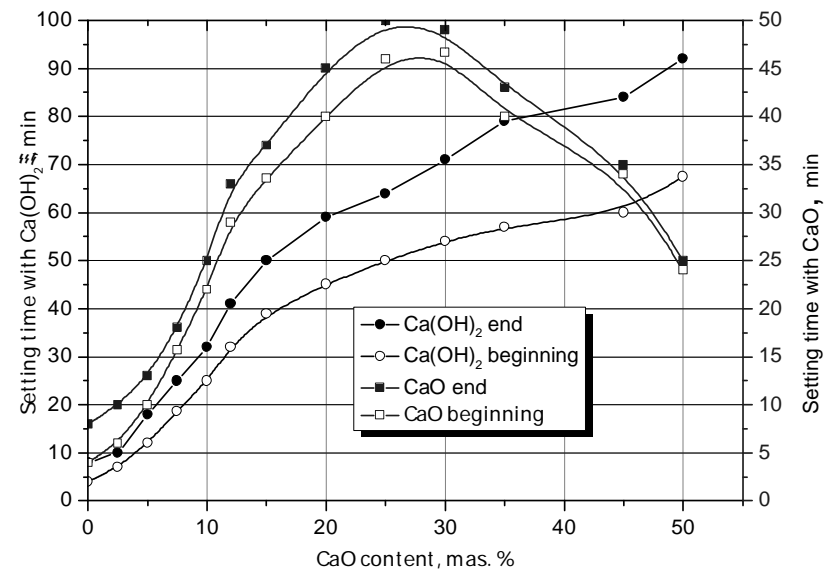

Fig. 1. $\mathrm{CaO}$ content $v s$. setting time of gypsum

The effect of $\mathrm{CaO}$ hydration hardening on physicomechanical properties of lime-gypsum stone is confirmed by the experiments under different hardening conditions. So, at the hardening under air-dry conditions (relative humidity is $70 \%$ ) the maximum stone strength is achieved at quicklime content of $25.0 \mathrm{wt} \%$. At samples storage over water the optimum lime content is $35.0 \mathrm{wt} \%$. Stone strength in water is $12.8 \mathrm{MPa}$ after 7 days (quicklime content is $42.0 \mathrm{wt} \%$ ). Thus, in the presence of gypsum the conditions for $\mathrm{CaO}$ hydration hardening are formed providing the increase in stone strength by 2.5 times compared with the strength of gypsum without additives. Such conditions are possible only in the presence of a great amount of liquid phase provided by the samples hardening in water.

We determined by the experiments that bihydrated gypsum changes the liming parameters. At gypsum content of $50 \mathrm{wt} \%$ the time for achieving maximum liming temperature increases from 2 to $35 \mathrm{~min}$ and the maximum temperature decreases from 378 to $338 \mathrm{~K}$. The gypsum effect is connected with the physico-chemical processes occurred on $\mathrm{CaO}$ surface. In the presence of sulfate-ions the bad-soluble sulfate layer is formed followed by the change of $\xi$-potential value, the decrease of water access rate and retardation of hydration reaction.

The phase composition of the hydration products was determined using different methods of physicochemical analysis. Thermal analysis data (Fig. 2a) show that after 1 day of hardening there are endoeffects at 428 and $445 \mathrm{~K}$, corresponding to water separation from $\mathrm{CaSO}_{4} \cdot 2 \mathrm{H}_{2} \mathrm{O}$, and at $762 \mathrm{~K}$ - corresponding to portlandite decomposition. Endoeffect at $1065 \mathrm{~K}$ is caused by calcite decomposition, one part of which is formed at stone carbonization and the other part is a component of quicklime. After 180 days of hydration we observe the shift of portlandite decomposition temperature to $765 \mathrm{~K}$ (Fig. 2b) due to the perfect structure and growth of $\mathrm{Ca}(\mathrm{OH})_{2}$ crystals during hydration hardening. Constant weight losses at 763-768 K reveal the absence of limegypsum stone carbonization.

Using SEM method we additionally obtained data concerning the structure of lime-gypsum stone under normal conditions of hardening. At the early stages of hardening (Figs. 3a and 3b) we observe a great number of $\mathrm{CaSO}_{4} \cdot 2 \mathrm{H}_{2} \mathrm{O}$ needle-shaped crystals covered by the formed portlandite. There is a small amount of unreacted $\mathrm{CaO}$ grains which touch each other (Fig. 3c). The stone pores are filled with larger crystals of gypsum, between which porltlandite hexagonal plates of 3-5 $\mu \mathrm{m}$ size are located (Fig. 3d).

During long-term hardening (180 days) in the presence of liquid phase the bihydrated gypsum is recrystallized and parallel oriented aggregates are formed (Fig. 4a), which are combined into fern-shaped configurations (Fig. 4b). This provides the increase of mechanical strength. 


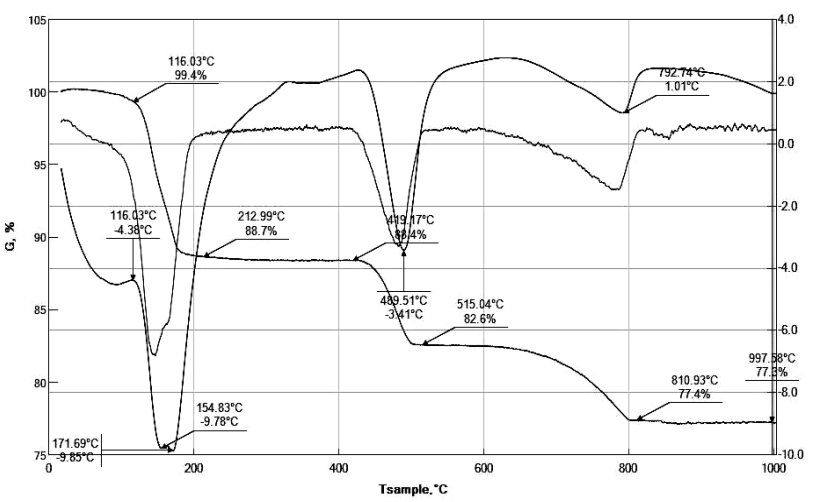

a)

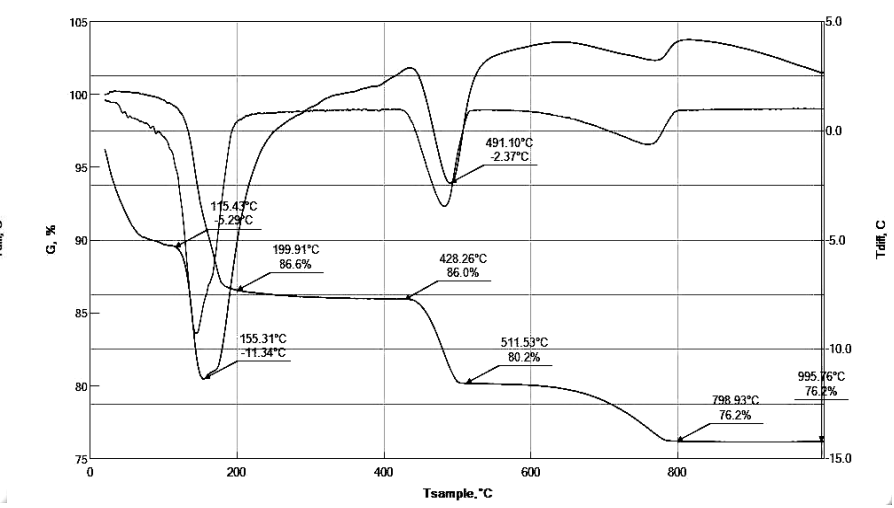

b)

Fig. 2. Derivatogramms of lime-gypsum stone after 1 (a) and 180 (b) days of hydration

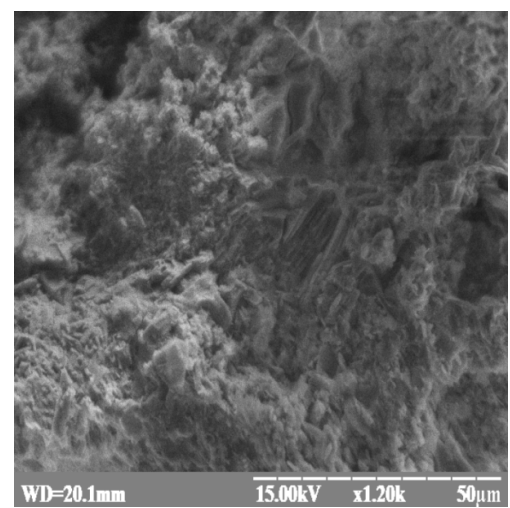

a)

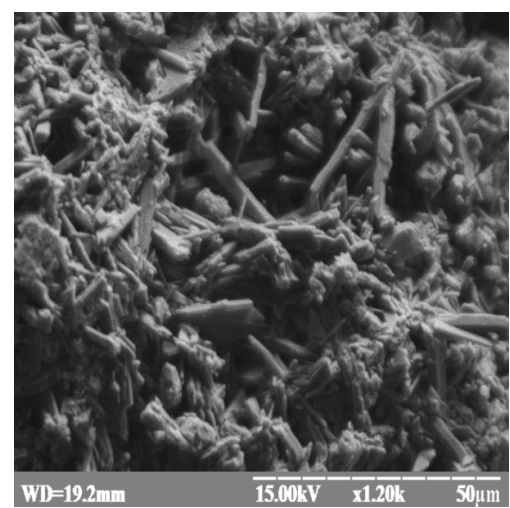

d)

The increase of reflexes intensity (001) was determined by XRD analysis in the solution with $\mathrm{SO}_{4}{ }^{2-}$ anions. The change of diffraction maxima intensity is explained by the effect of $\mathrm{SO}_{4}{ }^{2-}$ anions on habitus formation and morphology of $\mathrm{Ca}(\mathrm{OH})_{2}$ crystal phase.

According to the data of electron microprobe analysis (Fig. 4d) the $\mathrm{CaO}$ concentration on the surface of $\mathrm{CaSO}_{4} \cdot 2 \mathrm{H}_{2} \mathrm{O}$ crystals is $44.2 \%$. According to stoichiometry this value is equal to $35.1 \%$ indicating portlandite localization on the surface of gypsum as a thin layer composed of hexagonal crystals.

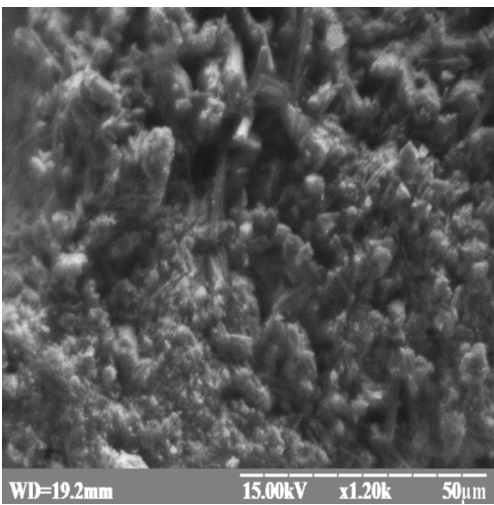

b)

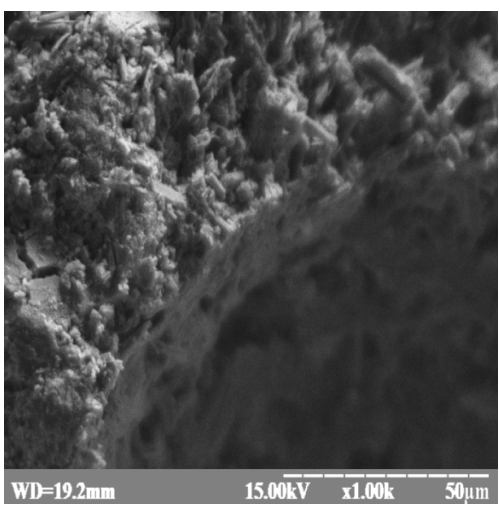

c)
Fig. 3. Microstructure of lime-gypsum stone after 1 day of hydration under normal conditions

To determine the character of $\mathrm{SO}_{4}{ }^{2-}$ anions effect we analyzed portlandite obtained via hydration in distilled water and $1 \% \quad \mathrm{H}_{2} \mathrm{SO}_{4}$ by means of IR-spectroscopy (Figs. 5 and 6).

There are great differences within the range of $\mathrm{OH}-$ groups stretching vibration $\left(3000-3800 \mathrm{~cm}^{-1}\right)$. Neat portlandite (Fig. 5) is characterized by clear band typical of $\mathrm{O}-\mathrm{H}$ bond at $3607 \mathrm{~cm}^{-1}$ and wide band at $3538-2950 \mathrm{~cm}^{-1}$. The presence of $\mathrm{SO}_{4}{ }^{2-}$ groups changes the spectrum view. For the main band the frequency value shifts toward the area of short waves (from 3607 to 


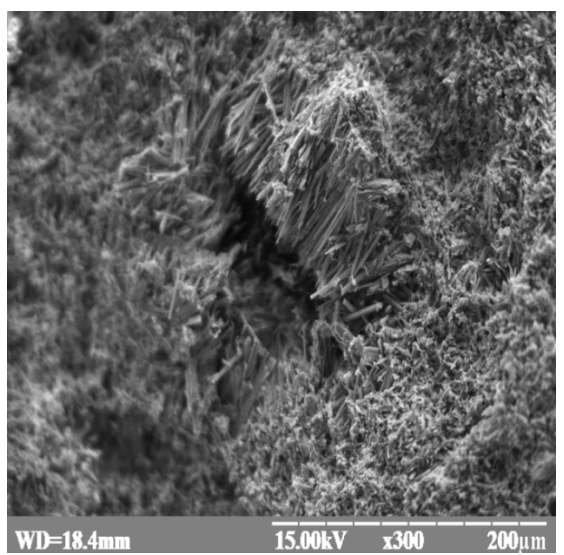

a)

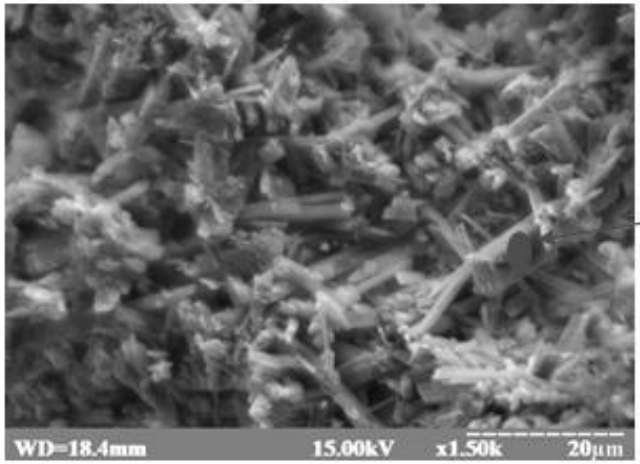

c)

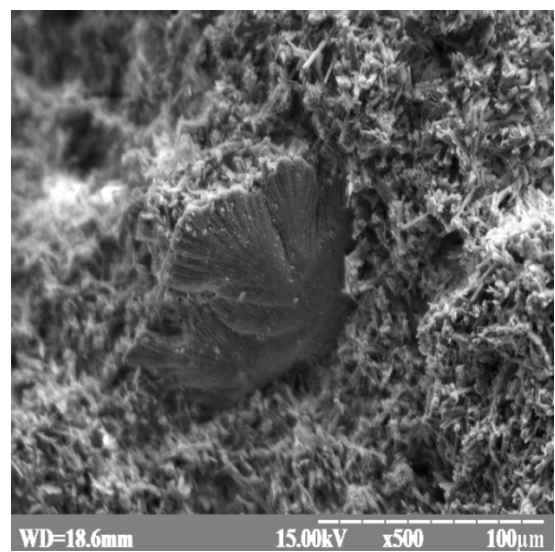

b)

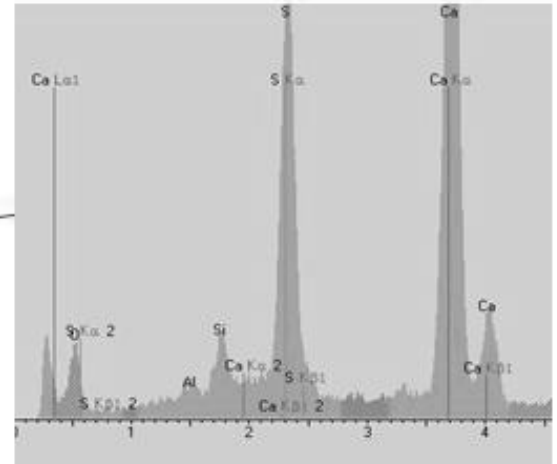

d)

Fig. 4. Microstructure (a-c) and EMPA analysis (d) of lime-gypsum stone after 180 days of hydration

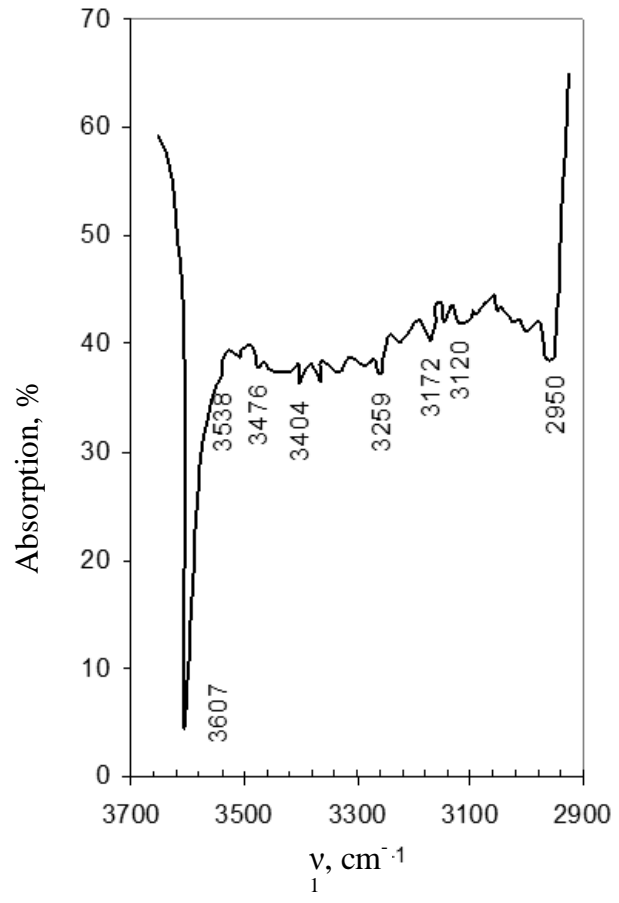

a)

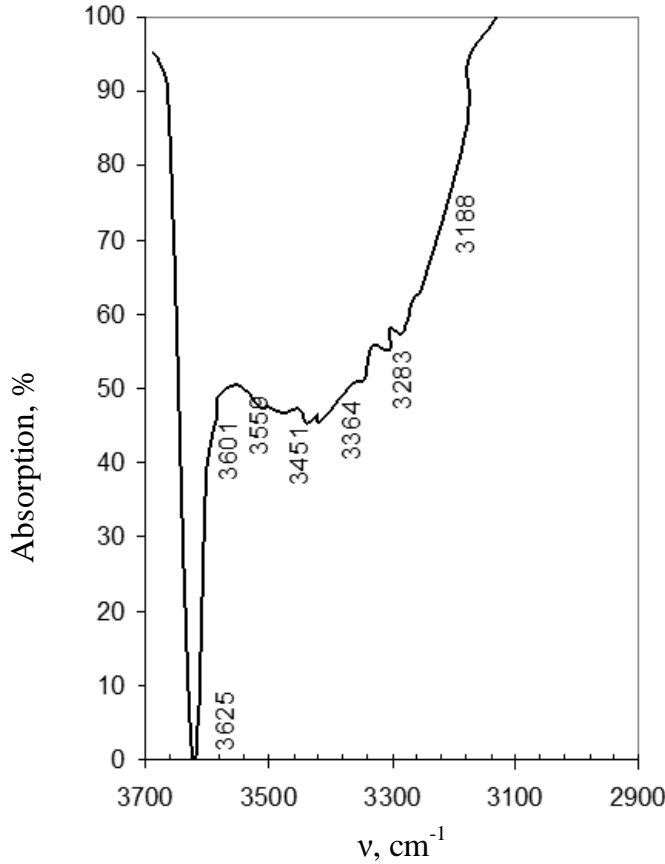

b)

Fig. 5. IR-spectra of $\mathrm{OH}$ group in $\mathrm{CaO}$ : without additives after 1 day of hydration (a) and with $1 \mathrm{~mol}^{\%} \mathrm{H}_{2} \mathrm{SO}_{4}$ (b) 


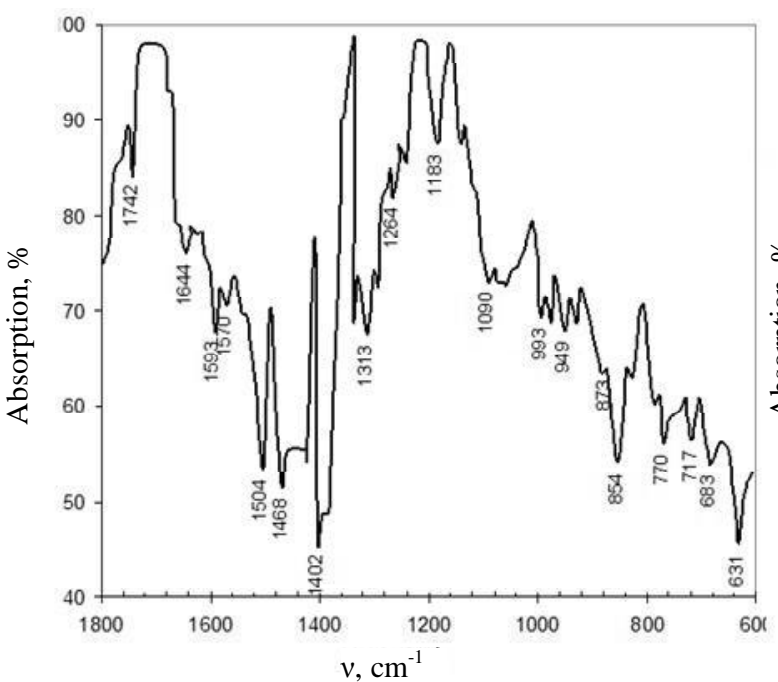

a)

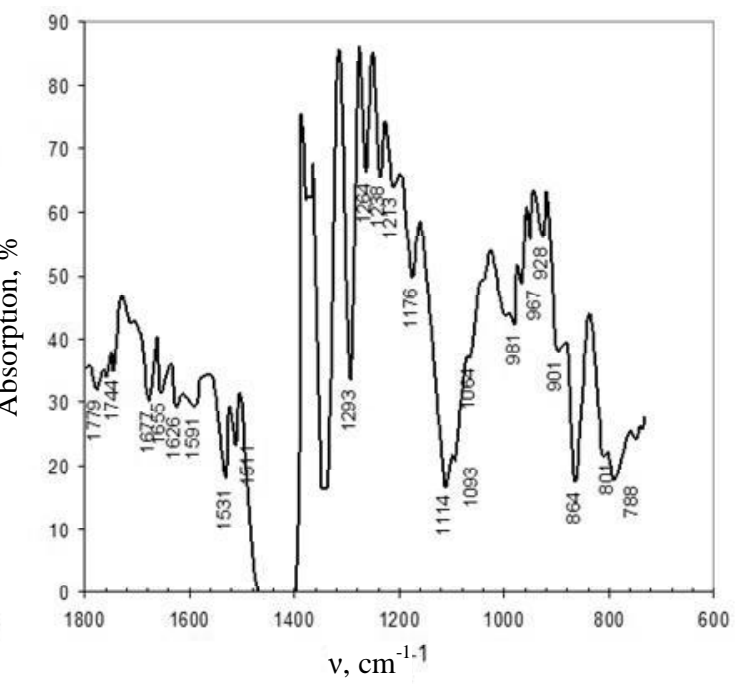

b)

Fig. 6. IR-spectra of $\mathrm{CaO}$ without additives after 1 day of hydration (a) and with $1 \mathrm{~mol} \% \mathrm{H}_{2} \mathrm{SO}_{4}$ (b)

$\left.3625 \mathrm{~cm}^{-1}\right)$; the wide band becomes more narrow and smooth. The structure of crystal, nature of anion and force of formed H-bonds influence the stretching vibrations. The increase in vibrations frequency for the samples with sulfate acid indicates the formation of strong hydrogen bonds of $\mathrm{H}_{2} \mathrm{O} \ldots \mathrm{SO}_{4}{ }^{2-}$ type.

Stretching and deformation vibrations of $\mathrm{CO}_{3}^{2-}$ anion are observed at 1468, 1090, 854 and $717 \mathrm{~cm}^{-1}$ (Fig. 6). There is a wide band within $1064-1114 \mathrm{~cm}^{-1}$ typical of $\mathrm{SO}_{4}$-group stretching vibrations.

Thus, in lime-gypsum binding agents with the increased amount of $\mathrm{CaO}$ the stone strength and water resistance increase due to the lime hydration hardening and formation of portlandite perfect crystals.

\section{Conclusions}

We vindicated the possibility of strong portlandite stone obtaining via regulation of hydration hardening in the compositions consisting of quick lime and bihydrated gypsum. The gypsum optimum content depends on hardening conditions. Thus, under dry air conditions the maximum strength of $13.0 \mathrm{MPa}$ is achieved while using $25 \mathrm{wt} \% \mathrm{CaO}$, that is 2.5 time higher than the strength of gypsum without additives.

SEM analysis confirms the change of portlandite crystals form and size in the presence of gypsum. At the beginning of hardening the great amount of $\mathrm{Ca}(\mathrm{OH})_{2}$ is a sponge mass located between needle-shape crystals of $\mathrm{CaSO}_{4} \cdot 2 \mathrm{H}_{2} \mathrm{O}$. After 90 days portlanide crystals transform into hexagonal plates $(3-5 \mu \mathrm{m})$ which fill the space between bihydrated gypsum crystals.

Different conditions of portlandite crystallization change the crystals morphology and affect physicomechanical characteristics of portlandite stone.
The developed methods of $\mathrm{CaO}$ hydration hardening may be used in binding compositions based on Portlandcement to produce non-autoclaved insulating aerated concrete which is hardened under high water content.

\section{References}

[1] Garrault S., Finot E., Lesniewska E. and Nonat A.: Mater. Struct., 2005, 38, 435.

[2] Barnes P. and Bensted J. (Eds.): Structure and Performance of Cements, $2^{\text {nd }}$ edn. Spon Press, London-NY 2002.

[3] Sanytskyi M.: Nauk. Visnyk Budivnytstva, 2007, 42, 179.

[4] Shpynova L., Chih V., Sanytskyi M. et al.: Fiziko-Khimichiskie Osnovy Formirovania Cementnogo Kamnia. Lvov 1981.

[5] Babushkin V.: Cement i Ego Primenenie, 1998, 5-6, 50.

[6] Pashchenko A.: Teoria Cementa. Kiev 1991.

[7] Ghosh S.: Advances in Cement Technology: Chemistry, Manufacture and Testing. CRC Press, 2003.

[8] Kurdowski W.: Infrastruktura Transportu, 2011, 4, 88.

[9] Peukert S.: Cementy powszechnego użytku i specjalne. Kraków 2000.

[10] Sersale R., Cioffi R. and Frigione G.: Cement Concrete Res., 1991, 21, 120.

Received: February 10, 2016 / Revised: M arch 26, 2016 / Accepted: July 13, 2016

\section{ПРО РОЛЬ ГІПСУ У ФОРМУВАННІ СТРУКТУРИ ПОРТЛАНДИТОВОГО КАМЕНЮ}

Анотація. Досліджено прочеси гідратаиії кальиію оксиду у присутності йонів $\mathrm{SO}_{4}^{2-}$ та встановлено умови, за яких утворюється портландитовий камінь з максимальними фізикомеханічними показниками. Отримані дані із впливу умов тверднення на фазовий склад та мікроструктуру портландитового каменю з додатками гіпсу двогідрату. Встановлений механізм гідратаційного тверднення СаО у присутності йонів $\mathrm{SO}_{4}^{2-}$.

Ключові слова: негашене вапно, портландит, гідратаційне тверднення, активований гіпс. 